\title{
Model Forest and its prospect in Nepal
}

\author{
Peter Bridgewater,Ph.D. ${ }^{1}$, Suraj Upadhaya ${ }^{2}$ \\ Corresponding Author : Suraj Upadhaya \\ Email : luckysuraj@gmail.com
}

\section{What is a Model Forest?}

The "Model Forest" concept, first initiated in Canada, has been developed throughout the world. It is a development process based upon partnership, through which individuals and groups representing a diversity of values work together in a common vision for the sustainable development of a landscape in which forests represent a critical feature. This concept appears as a new and original instrument of territorial governance, well adapted to address the recurrent challenges of the climate and biodiversity change, which requires a large and multifunctional approach. Crucial is the role of people.

Three attributes are central to a model forest:

- A large-scale geographic area representing the full range of its forest values including environmental, social and economic values;

- A fully inclusive exercise in which people who have an interest in their region's natural resources agree on a process for determining local sustainability priorities and goals, and then work collaboratively to address them;

- A shared effort focused on achieving Sustainable Forest Management in tangible ways, from the field level to the policy level, with stakeholders continually involved in developing, testing and sharing innovative landscape approaches to Sustainable Forest Management.

Key descriptors qualifying "model forest", which emerge from this set of attributes of a model forest and its network, include:

- innovative,

- $\quad$ partnership (voluntary, stakeholders),

- $\quad$ Sustainable (social, cultural, environmental and economic).

${ }^{1}$ Chair, Joint Nature Conservation Committee

${ }^{2}$ Student, Kathmandu Forestry College 
Thus, Model Forests have strong emphases on partnership and collaboration, being sustainable and innovative in approaches to forest management. Globally there are over 55 Model forests now recognised and theses are organised into an international network (The International model forest network - IMFN). The latest Model Forest is the Carood Watershed Model Forest, officially inaugurated as a Model Forest in September 2010. It is located on the Island of Bohol in the Philippines and is comprised of parts of six municipalities on the eastern part of the Island. It encompasses 20,472 hectares of land, of which approximately $10 \%$ is forested. The role of the Carood MF is to; sustain resources and allow people to co-manage the area. To achieve this the Philippines government has issued some six Community-based Forest Management Agreements (CBFMAs) in Carood, for reforestation projects covering nearly 2,500 hectares of land, covering all types of terrain from uplands to coastal mangrove forests.

\section{An International Network}

Model Forests have been convened into an international network (IMFN), where a global community of shared aspirations and practice can meet. The overall strength of the IMFN lies in its independence and strong stakeholder ownership. The IMFN is a voluntary association of partners from around the world, using a shared approach to address the common goal of sustainable management of forested landscapes.

The IMFN developed from the innovative site-based approach combining social, cultural and economic needs of local communities with the long-term sustainability of forest landscapes. It also aspires to be a knowledge-based organisation serving all forest nations. Effectively, this means it could (and should) have global reach across all member states of the UN, although obviously with different emphases. And in today's parlance, perhaps IMFN should also see itself as a learning, as well as a knowledge-based organisation. After all, it is important to recall that a Model Forest is a voluntary and partnership-based approach for moving collaboratively toward Sustainable Forest Management.

These descriptions of Model Forests reflect those used by other institutions for forested landscapes. For example, forested areas of UNESCO's World Network of Biosphere Reserves are also described (and act) as areas that combine the social, cultural and economic needs of local communities with the aim of ensuring long-term sustainability, as do some areas under UNESCO's World Heritage Convention. And in fact one or two MF's are wholly or partly Biosphere Reserves.

\section{Sustainable Forestry Management in Model Forests}

Sustainable Forest Management is recognised (by FAO) as the interlinkage, in a particular ecological space, of the following seven thematic elements;

(1) Extent of forest resources;

(2) Biological diversity;

(3) Forest health and vitality; 
(4) Productive functions of forest resources;

(5) Protective functions of forest resources;

(6) Socio-economic functions;

(7) Legal, policy and institutional framework.

These thematic elements, also acknowledged by the United Nations Forum on Forests (UNFF), are based on the criteria of the on-going regional/international processes on criteria and indicators for sustainable forest management. The thematic elements are also used in the FAO-led global Forest Resources Assessment (FRA) as a reporting framework.

\section{Extent of forest resources}

The theme expresses an overall desire to have significant forest cover and stocking, including trees outside forests, to support the social, economic and environmental dimensions of forestry. For example, the existence and extent of specific forest types are important as a basis for conservation efforts. The theme encompasses ambitions to reduce deforestation and to restore and rehabilitate degraded forest landscapes. This theme also includes the important function of forests and trees outside forests to store carbon and thereby contribute to moderating the global climate.

\section{Biological diversity}

The theme concerns the conservation and management of biological diversity at the ecosystem (landscape), species and genetic levels. Such conservation, including protecting areas with fragile ecosystems, ensures that diversity of life is maintained, and provides opportunities to develop new products, for example medicines, in the future. Genetic improvement is also a means to improve forest productivity, for example to ensure a high wood production in intensively managed forests.

\section{Forest health and vitality}

Forests need to be managed so that the risks and impacts of unwanted disturbances are minimized, including wildfires, airborne pollution, storm felling, invasive species, pests, diseases and insects. Such disturbances may impact social, economic and environmental dimensions of forestry.

\section{Productive functions of forest resources}

Forests and trees outside forests provide a wide range of wood and non-wood forest products. The theme expresses the desire to maintain a high and valuable supply of primary forest products, while at the same time ensuring that production and harvesting are sustainable and do not compromise management options of future generations. 


\section{Protective functions of forest resources}

The theme addresses the role of forests and trees outside forests to help moderate soil, hydrological and aquatic systems. This includes the maintenance of clean water including e.g. healthy fish populations, as well as the reduction of risks or impacts of floods, avalanches, erosion and droughts. Protective functions of forest resources also contribute to ecosystem conservation efforts and have strong cross-sectoral aspects of high benefit to agriculture and rural livelihoods.

\section{Socio-economic functions}

The theme addresses the contributions of forest resources to the overall economy, for example through employment, values generated through processing and marketing of forest products and energy, trade, and investments in the forest sector. The theme also addresses the important functions of forests in hosting and protecting sites and landscapes that have high cultural, spiritual or recreational values, and thus includes aspects of land tenure, indigenous and community management systems, and traditional knowledge.

\section{Legal, policy and institutional framework}

The theme includes the legal, policy and institutional arrangements necessary to support the first six themes, including participatory decision making; governance; law enforcement; and monitoring and assessment of progress. The theme also addresses broader societal aspects: including fair and equitable use of forest resources; scientific research and education, infrastructure arrangements to support the forest sector; technology transfer and capacity building; and public information and communication.

\section{Combining sustainable forest attributes in the IMFN}

While any Model Forest in the network is essentially responsive to all seven themes described above, the voluntary, partnership-based approaches of model forests fully represent the environmental, social and economic forces at play within the forested landscape. Recognising these seven the IMFN has developed six strategic objectives namely:

- Development and application of network-wide operating standards and norms;

- Addressing geopolitical and forest ecosystem gaps in the IMFN community;

- Internationalization through strategic partnerships and support;

- Accelerating innovation through a robust networking program;

- Elaboration and delivery of a network-wide research agenda; and

- Contributing concretely to key national and international policy objectives for the sustainable management of forested landscapes and natural resources.

These objectives set the IMFN clearly apart from those programmes and organisations dealing solely with normative (legal, administrative) processes, from those dealing with 
purely research focused needs, and from those solely involved in forestry management sensu stricto. These strategic objectives can help in the area of forest management, providing a framework for overall sustainability, with express involvement of local communities, who can feel connected to a global network through their own activities.

\section{And in Nepal?}

While China and India have embraced the IMFN with a Model forest each. Nepal has yet to invoke the concept. Yet there are many examples where this might be possible.

In Asia, China and India are active participants, and there is an idea of a focus on Himalayan forests - So there is a clear role for Nepal to play in this development.

But a Model Forest is about linking forestry to people, and people to environment. Environmental management, through forestry, can help manage landscapes and alleviate poverty. Nepal has many possibilities to establish Model Forests across the length and breadth of the country, and to contribute some of its important experiences through the dramatic altitudinal range of the different forested landscapes found throughout the country. Even more important than the environmental aspects is the human dimension, and the basic legal framework of Community Forestry in Nepal appears to allow a degree of social support not always available when Model Forests are being established.

The area around National Park would make an ideal Model Forest, with little lead-in needed. Using the National Park (World Heritage) site as a core, the Buffer zone Community Forests surrounding the Park and other community the Model Forest can be well developed.

Nepal already posses a good network of Community forest with more than 16000 users group which are practicing the democracy in a grassroots level. Because of the success of CF concept, Nepal is universally known as Country of Community Forest. Likewise adoption of Model Forest Concept in country can be another way of making Nepal famous in Nepal and can give an ample contribution on achieving millennium development goals. Simultaneously, there will be a direct role in mitigation of Climate Change effect through afforestation.

So a model Forest in Nepal could help develop and promote sustainable forestry, using the uniquely successful community forestry approach already practiced. And this can help other countries to follow these great ideas!

\section{References}

IMFN 2011. www.imfn.net 